\title{
Unusual case of elevator deficit: looking beyond the extraocular muscles
}

\author{
Priyanka Ramesh, ${ }^{1}$ Rebika Dhiman, ${ }^{2}$ Sanjay Sharma, ${ }^{3}$ Rohit Saxena ${ }^{2}$
}

'Ophthalmology, Kasturba Medical College, Manipal, Manipal Academy of Higher Education, Manipal, Karnataka, India

2Ophthalmology, All India Institute of Medical Sciences, New Delhi, India

${ }^{3}$ Radiodiagnosis, All India Institute of Medical Sciences, New Delhi, India

Correspondence to Dr Rohit Saxena; rohitsaxena80@yahoo.com

Accepted 13 December 2020

Check for updates

(C) BMJ Publishing Group Limited 2021. No commercial re-use. See rights and permissions. Published by BMJ.

To cite: Ramesh P, Dhiman $\mathrm{R}$ Sharma $S_{\text {, et al. BMJ Case }}$ Rep 2021;14:e239344. doi:10.1136/bcr-2020239344

\section{DESCRIPTION}

A 70-year-old man, a non-smoker, presented with diplopia in upgaze for the past 4 months. There was no history of trauma, fever, nasal congestion, discharge or thyroid-related symptoms or no history of sinus surgery. On examination, anterior and posterior segment including pupillary reaction and visual acuity were normal. Slight limitation of upgaze was noted in the right eye with associated vertical diplopia (figures 1 and 2). Hirschberg test showed 5-10 degrees of hypotropia in upgaze, and diplopia charting documented the diplopia (figure 1G). There was no enophthalmos or hypoglobus. The thyroid profile was normal. Non-contrast CT of the orbit and paranasal sinuses revealed right chronic maxillary sinusitis with blockage of the ostium, deviation of the nasal septum and atelectasis of maxillary sinus leading to sagging of the inferior orbital wall. These findings were suggestive of 'silent sinus syndrome' (figures 3 and 4), causing sagging of the inferior rectus and the surrounding soft tissue, thus causing upgaze limitation and diplopia. The patient was referred to the Otorhinolaryngology department where he was managed conservatively.

Vertical diplopia occurs due to an abnormality in either the extraocular muscles or the nerve supplying it. Common differentials are thyroid ophthalmopathy, blow-out fracture with inferior rectus entrapment, neurological causes like superior oblique palsy, neuromuscular junction abnormalities like myasthenia gravis or, in some cases, cysticercosis of the extraocular muscles. ${ }^{1}$

'Silent sinus syndrome' is a rare condition where chronic maxillary sinusitis presents with progressive enophthalmos and hypoglobus in the absence of any symptoms of a sino-inflammatory disease. ${ }^{2}$ Kass et

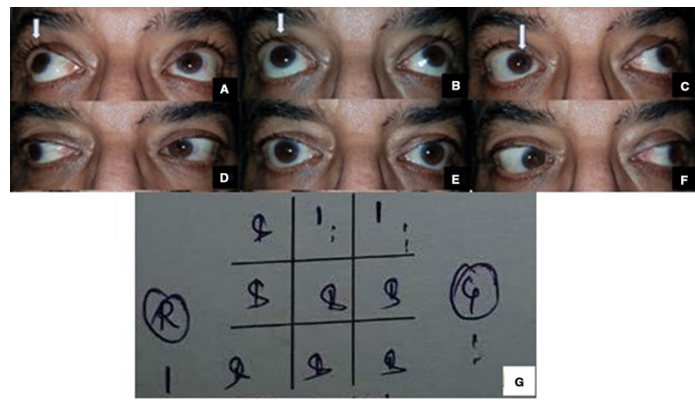

Figure 1 Clinical photograph in gazes (A) dextroelevation, (B) sursumversion (C) levoelevation (D) dextroversion, $(E)$ primary gaze, $(F)$ levoversion showing limitation of elevation in right eye in gazes $(A),(B),(C)$. Diplopia charting showing vertical diplopia $(G)$.

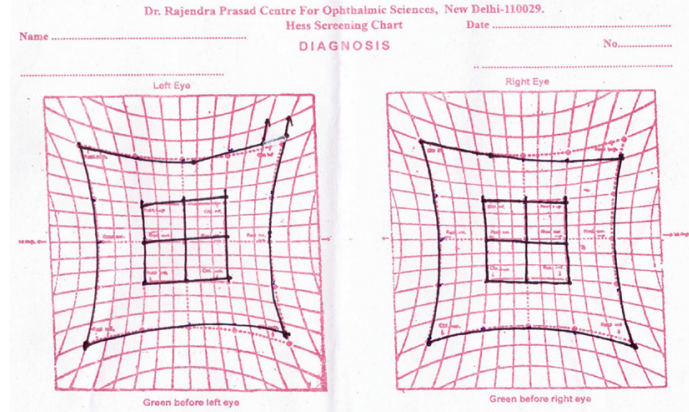

Figure 2 Hess chart showing limitation of movement in the right eye.

al reported 22 cases of the syndrome, of which 5 had ocular signs. ${ }^{3}$ Babar-Craig et al reported 16 patients, of which diplopia was present in 32\% and hypoglobus in $44 \% .^{4}$ These ocular features are attributed to long-term ongoing inflammation in the sinus that blocks the osteomeatal complex creating a negative pressure, leading to the collapse of the orbital floor. ${ }^{5}$ Diplopia, if present, is often associated with enophthalmos or hypoglobus. It is
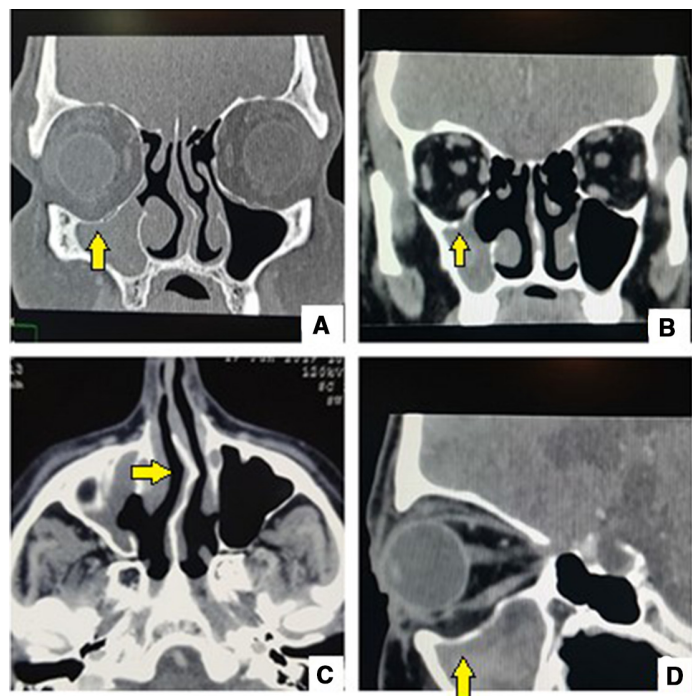

Figure 3 (A) Coronal non-contrast CT of paranasal sinuses and orbit showing contracted right maxillary sinus with inspissated secretions causing sagging of the right inferior orbital wall. Features represent right silent sinus syndrome due to long-standing chronic maxillary sinusitis. (B) Coronal section showing opaque right maxillary sinus with sinking of the inferior orbital wall.

(C) Axial section showing deviation of the nasal septum.

(D) Sagittal section showing bowing of the inferior orbital wall. 


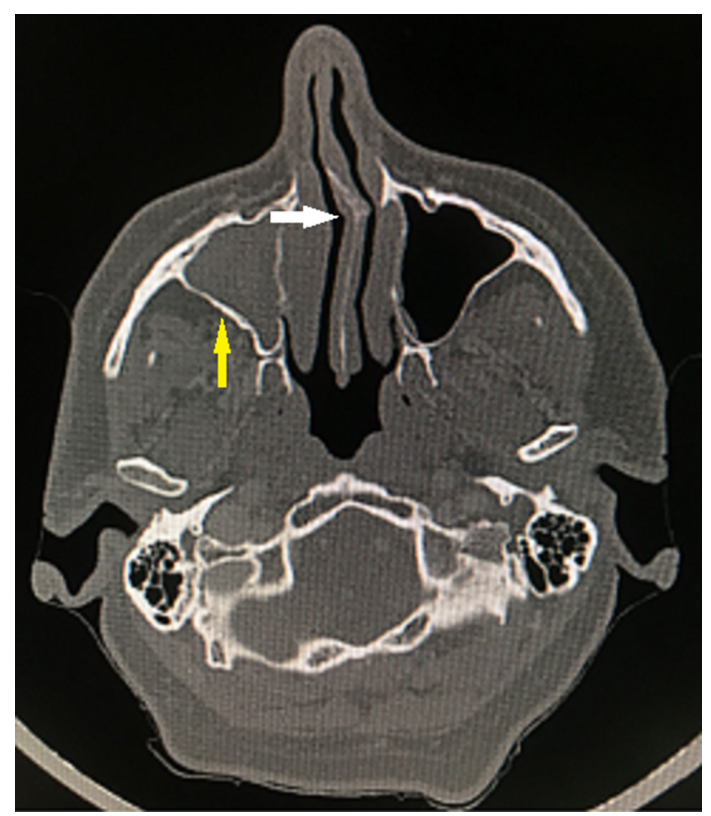

Figure 4 Axial non-contrast CT of paranasal sinus showing deviation of the nasal septum to the left side (white arrow) and mild inward bowing of the posterolateral wall of the maxillary sinus (yellow arrow).

more commonly seen in middle-aged population with a mean age of presentation of 38.3 years. ${ }^{3}$ The occurrence in children is rarely encountered as seen in few case reports. ${ }^{46}$ Management involves endoscopic sinus surgery to establish free ventilation to the sinus along with orbital reconstruction with implants. Some cases also have spontaneous resolution of ocular symptoms after sinus surgery. ${ }^{4}$ Our patient presented early in the disease process with diplopia due to inferior sagging of the orbital floor along with inferior rectus and its sheath without hypoglobus or enophthalmos.

\section{Learning points}

- All cases of diplopia might not be explained by nerve palsy or extraocular muscle abnormalities.

- Imaging plays an important role in diagnosing certain unusual cases of diplopia.

Contributors PR contributed to the acquisition of data, drafting the manuscript and has agreed to be accountable for the article. RD contributed to drafting the manuscript, revising it critically for intellectual content and agreed to be accountable for the article. SS contributed to analysis and interpretation of data and agreed to be accountable for the article. RS contributed to the conception, design, interpretation of data, final approval of the version sent for publication and agreed to be accountable for the article.

Funding The authors have not declared a specific grant for this research from any funding agency in the public, commercial or not-for-profit sectors.

Competing interests None declared.

Patient consent for publication Obtained.

Provenance and peer review Not commissioned; externally peer reviewed.

\section{REFERENCES}

1 Acierno MD. Vertical diplopia. Semin Neurol 2000;20:21-30.

2 Soparkar CN, Patrinely JR, Cuaycong MJ, et al. The silent sinus syndrome. A cause of spontaneous enophthalmos. Ophthalmology 1994;101:772-8.

3 Kass ES, Salman S, Rubin PA, et al. Chronic maxillary atelectasis. Ann Otol Rhinol Laryngol 1997;106:109-16.

4 Babar-Craig H, Kayhanian H, De Silva DJ, et al. Spontaneous silent sinus syndrome (imploding antrum syndrome): case series of 16 patients. Rhinology 2011;49:315-7.

5 Numa WA, Desai U, Gold DR, et al. Silent sinus syndrome: a case presentation and comprehensive review of all 84 reported cases. Ann Otol Rhinol Laryngol 2005; 114:688-94

6 Chang DT, Truong MT. A child with silent sinus syndrome and spontaneous improvement after sinus surgery. Int J Pediatr Otorhinolaryngol 2014;78:1993-5.

Copyright 2021 BMJ Publishing Group. All rights reserved. For permission to reuse any of this content visit

https://www.bmj.com/company/products-services/rights-and-licensing/permissions/

BMJ Case Report Fellows may re-use this article for personal use and teaching without any further permission.

Become a Fellow of BMJ Case Reports today and you can:

- Submit as many cases as you like

- Enjoy fast sympathetic peer review and rapid publication of accepted articles

- Access all the published articles

- Re-use any of the published material for personal use and teaching without further permission

Customer Service

If you have any further queries about your subscription, please contact our customer services team on +44 (0) 2071111105 or via email at support@bmj.com.

Visit casereports.bmj.com for more articles like this and to become a Fellow 